\title{
PENGARUH KEPUTUSAN PENDANAAN, KEPUTUSAN INVESTASI DAN PROFITABILITAS TERHADAP NILAI PERUSAHAAN \\ (Pada Sektor Aneka Industri yang Terdaftar di Bursa Efek Indonesia Periode 2010-2014)
}

\author{
Basuki $^{1}$ \\ *Prodi Akuntansi, Fakultas Ekonomi dan Bisnis, Universitas Muhammadiyah \\ Tangerang \\ *mr.basuki.tng@gmail.com ${ }^{1}$ \\ Siti Yulianah ${ }^{2}$ \\ *Prodi Akuntansi, Fakultas Ekonomi dan Bisnis, Universitas Muhammadiyah \\ Tangerang \\ *mr.basuki.tng@gmail.com²
}

\begin{abstract}
ABSTRAK
Mengoptimalkan nilai perusahaan merupakan salah satu tujuan perusahaan. Semakin tinggi nilai perusahaan, maka semakin sejahtera para pemegang saham. Penelitian ini bertujuan untuk melihat pengaruh keputusan pendanaan, keputusan investasi dan profitabilitas terhadap nilai perusahaan. Populasi dalam penelitian ini adalah perusahaan manufaktur sektor aneka industri yang terdaftar di Bursa Efek Indonesia periode 20112014. Sampel dalam penelitian ini menggunakan teknik purposive sampling berjumlah 12 perusahaan. Hasil penelitian ini menunjukkan bahwa secara simultan keputusan pendanaan, keputusan investasi dan profitabilitas berpengaruh positif dan signifikan terhadap nilai perusahaan dengan nilai $t_{\text {hitung }}$ sebesar $16,466>2,86$. Secara parsial keputusan pendanaan tidak memiliki pengaruh yang signifikan terhadap nilai perusahan dengan nilai $t_{\text {hitung }}$ sebesar $-0,328<2,026$, keputusan investasi tidak memiliki pengaruh yang signifikan terhadap nilai perusahaan dengan nilai $t_{\text {hitung }}$ sebesar $-1,057<2,026$ dan profitabilitas berpengaruh positif signifikan terhadap nilai perusahaan dengan nilai $t_{\text {hitung }}$ sebesar 6,456 $>2,026$.
\end{abstract}

Kata Kunci : Keputusan Pendanaan, Keputusan Investasi, Profitabilitas, Nilai Perusahaan. 


\section{PENDAHULUAN}

Penelitian ini tentang nilai perusahaan dimana nilai perusahaan dipengaruhi oleh keputusan pendanaan, keputusan investasi dan profitabilitas. Nilai perusahaan dapat dilihat dari besarnya kemampuan perusahaan membayar dividen. Meningkatnya price eraning ratio, maka akan berpengaruh terhadap peningkatan nilai perusahaan (Bhekti, 2013). Apabila perusahaan memperoleh keuntungan yang makin besar maka nilai saham akan ikut meningkat sebaliknya apabila perusahaan mengalami kerugian maka nilai saham perusahaan akan jatuh. Naik turunnya nilai saham merupakan ukuran keberhasilan perusahaan (Kasmir, 2010).

Keputusan ivestasi merupakan keputusan terhadap aktiva yang akan dikelola oleh perusahaan, keputusan investasi berpengaruh secara langsung terhadap besarnya rentabilitas investasi dan aliran kas perusahaan untuk waktuwaktu yang akan datang. Berdasarkan Husnan (2000) dalam Yulia Efni (2012) tujuan keputusan investasi perusahaan adalah memaksimumkan Net Present Value (NPV) karena NPV yang positif akan meningkatkan kekayaan riil. Suatu perusahaan untuk dapat melangsungkan aktivitas operasinya haruslah berada dalam keadaan yang menguntungkan (profitable). Tanpa adanya keuntungan akan sulit bagi perusahaan untuk menarik modal dari luar. Perusahaan yang memiliki tingkat profitabilitas yang tinggi akan diminati sahamnya oleh investor. Sehingga, dengan demikian profitabilitas dapat mempengaruhi nilai perusahaan (Ummi, dkk. 2012).

Penelitian mengenai pengaruh keputusan investasi terhadap nilai perusahaan juga dilakukan oleh Leli dan
Barbara (2011), Oktaviana (2013), Mokhamat dan Denica (2010) yang menyatakan bahwa keputusan investasi (PER) berpengaruh positif terhadap nilai perusahaan. Hal ini berarti dengan meningkatnya investasi yang dilakukan oleh perusahaan maka akan berpengaruh terhadap nilai perusahaan.

Penelitian mengenai pengaruh profitabilitas terhadap nilai perusahaan telah dilakukan oleh beberapa peniliti, diantaranya Bhekti (2013) menyatakan bahwa profitabilitas berpengaruh terhadap nilai perusahaan. Penelitian Ummi, dkk (2012), Ayu dan Ary (2013) menyatakan bahwa profitabilitas memiliki pengaruh yang positif signifikan terhadap nilai perusahaan. Hal ini berarti semakin tinggi nilai profit yang didapat maka akan semakin tinggi nilai perusahaan.

Tujuan didirikannya perusahaan adalah mencapai keuntungan maksimal atau laba (profit) yang sebesarsebesarnya serta memaksimalkan nilai perusahaan. Tujuan perusahaan dalam memperoleh laba yang maksimal dimaksudkan untuk menjaga kelangsungan hidup perusahaan serta untuk kemakmuran atau kesejahteraan para pemilik perusahaan, tetapi tujuan ini sering tidak sejalan dengan tujuan pihak manajemen sebagai pengendali operasional perusahaan. Hal ini menimbulkan konflik antara pemegang saham dan manajemen perusahaan. Konflik kepentingan tersebut biasa disebut dengan konflik agensi.

\section{Rumusan Masalah}

Rumusan masalah yang akan dibahas dalam penelitian ini, sebagai berikut: 
1. Apakah terdapat pengaruh positif secara simultan atau bersama-sama keputusan pendanaan, keputusan investasi dan profitabilitas terhadap nilai perusahaan?

2. Apakah terdapat pengaruh positif keputusan pendanaan terhadap nilai perusahaan?

3. Apakah terdapat pengaruh positif keputusan investasi terhadap nilai perusahaan?

4. Apakah terdapat pengaruh positif profitabilitas terhadap nilai perusahaan?

\section{Tujuan Penelitian}

Tujuan dalam penelitian ini, sebagai berikut :

1. Untuk mengetahui dan menganalisis pengaruh keputusan pendanaan, keputusan investasi dan profitabilitas terhadap nilai perusahaan

2. Untuk mengetahui dan menganalisis pengaruh keputusan pendanaan terhadap nilai perusahaan

3. Untuk mengetahui dan menganalisis pengaruh keputusan investasi terhadap niali perusahaan

4. Untuk mengetahui dan menganalisis pengaruh profitabilitas terhadap nilai perusahaan.

\section{KAJIAN TEORITIS DAN HIPOTESIS PENELITIAN Kajian Teoritis}

Teori keagenan mendeskripsikan hubungan antara pemegang saham (shareholders) sebagai prinsipal dan manajemen sebagai agen. Manajemen merupakan pihak yang dikontrak oleh pemegang saham untuk bekerja demi kepentingan pemegang saham. Dalam teori agensi dijelaskan bahwa terdapat perbedaan perilaku antara pemegang saham (prinsipal) dan manajernya (agen). Dalam praktek sering kali antara manajer dengan pemegang saham terlibat konflik (agency problem), sehingga perlu di atasi secara professional (Kasmir, 2010).

Agency problem dapat terjadi antara manajer dengan pemegang saham atau antara kreditur dengan pemegang saham. Konflik antara kreditur dengan pemegang saham dapat terjadi karena kreditur memiliki hak atas sebagian laba dan sebagian aset perusahaan terutama dalam hal kebangkrutan (D. Agus Sarjito dan Martono, 2012).

Signalling theory menekankan kepada pentingnya informasi yang dikeluarkan oleh perusahaan terhadap keputusan investasi pihak di luar perusahaan. Informasi merupakan unsur penting bagi investor dan pelaku bisnis, karena informasi pada hakekatnya menyajikan keterangan, catatan atau gambaran baik untuk keadaan masa lalu, saat ini maupun keadaan masa yang akan datang bagi kelangsungan hidup suatu perusahaan dan bagaimana pasaran efeknya. Informasi yang lengkap, relevan, akurat dan tepat waktu sangat diperlukan oleh investor di pasar modal sebagai alat analisis untuk mengambil keputusan.

Signalling theory menyatakan bahwa keputusan investasi yang diambil perusahaan akan memberikan sinyal positif tentang pertumbuhan perusahaan dimasa yang akan datang, sehingga meningkatkan harga saham di pasar modal yang merupakan salah satu 
indikator nilai perusahaan. Menurut Dermawan (2013) Pengumuman suatu penawaran saham pada umumnya diterima sebagai "pertanda (signal)" bahwa prospek perusahaan yang terlihat oleh manajemennya tidak bagus. Sebaliknya, suatu penawaran hutang diterima sebagai suatu pertanda positif. Ummi, Gatot dan Ria (2012), menyatakan jika manajer memiliki keyakinan bahwa prospek perusahaan baik, dan karenanya ingin harga saham meningkat, manajer tersebut tentunya ingin mengkomunikasikan hal tersebut kepada para investor.

Nilai perusahaan didefinisikan sebagai nilai pasar karena nilai perusahaan dapat memberikan kemakmuran pemegang saham secara maksimum apabila harga saham perusahaan meningkat (Hasnawati, 2005 dalam Leli dan Barbara, 2011). Kasmir (2010) menyatakan bahwa nilai perusahaan dapat dilihat dan diukur dari harga saham perusahaan yang bersangkutan dari waktu ke waktu.

Menurut Fama (1978) dalam Ayu dan Ari (2013) harga saham terbentuk atas permintaan dan penawaran investor sehingga harga saham tersebut dapat dijadikan proksi nilai perusahan. Harga pasar dari saham perusahaan yang terbentuk atas penawaran dan permintaan investor mencerminkan nilai aset perusahaan yang sesungguhnya. Nilai perusahaan dapat pula dipengaruhi oleh besar kecilnya profitabilitas yang dihasilkan oleh perusahaan (Bhekti, 2013).

Keputusan pendanaan merupakan keputusan yang berkaitan dengan jumlah dana yang disediakan perusahaan, baik yang bersifat utang atau modal sendiri (Kasmir 2010). Sumber pendanaan didalam perusahaan dibagi kedalam dua kategori yaitu sumber pendanaan internal dan sumber pendanaan eksternal. Sumber pendanaan internal dapat diperoleh dari laba ditahan dan depresiasi aktiva tetap sedangkan sumber pendanaan eksternal dapat diperoleh dari para kreditur yang disebut hutang (Leli dan Barbara, 2011). Keputusan pendanaan dalam penelitian ini diproksikan menggunakan Debt to Equity Ratio.

Menurut Arifin dalam Mokhamat dan Denica (2010) investasi adalah kegiatan menunda konsumsi untuk mendapatkan (nilai) konsumsi yang lebih besar di masa yang akan datang. Sebuah keputusan investasi dikatakan optimal jika pengaturan waktu konsumsi tersebut dapat memaksimumkan ekspektasi utilitas (expected utility). Sedangkan menurut Tandeilin dalam Mokhamat dan Denica (2010) investasi adalah komitmen atas sejumlah dana lainnya yang dilakukan pada saat ini, dengan tujuan memperoleh sejumlah keuntungan di masa yang akan datang. Secara umum investasi bisa dalam bentuk investasi nyata (real assets), misalnya tanah, emas, mesin, bangunan dan lain-lain, serta bisa pula investasi dalam aktiva keuangan (financial assets) seperti deposito maupun berupa pemberian surat-surat berharga berupa saham dan obligasi.

Profitabilitas atau laba merupakan pendapatan dikurangi beban dan kerugian selama periode pelaporan. Analisis mengenai profitabilitas sangat penting bagi kreditor dan investor ekuitas. Bagi kreditor, laba merupakan sumber pembayaran bunga dan poko pinjaman. Sedangkan bagi investor ekuitas, laba merupakan salah satu 
faktor penentu perubahan nilai efek. Hal yang terpenting bagi perusahaan adalah bagaimana laba tersebut bisa memaksimalkan pemegang saham bukan seberapa besar laba yang dihasilkan oleh perusahaan (Ayu dan Ari, 2013). Profitablitas dalam penelitian ini diproksikan menggunakan Return on Equity.

\section{Hipotesis Penelitian}

Adapun hipotesis penelitian ini, sebagai berikut:

\section{Pengaruh Keputusan Pendanaan, Keputusan Investasi dan Profitabilitas Terhadap Nilai Perusahaan}

Yulia, dkk (2013) menemukan bahwa keputusan investasi dan pendanaan berpengaruh positif dan signifikan terhadap nilai perusahan. Ayu dan Ary (2013) menemukan bahwa profitabilitas berpengaruh positif dan signifikan terhadap nilai perusahaan. Penelitian yang dilakukan oleh Ummi, dkk (2012) menemukan bahwa profitabilitas memiliki pengaruh yang positif signifikan tehadap nilai perusahaan. Hal ini dapat diartikan bahwa hutang merupakan pertanda positif dari perusahaan. Sehingga para investor mampu mengambil keputusan untuk berinvestasi dengan melihat sinyal-sinyal yang diberikan oleh perusahaan. Berdasarkan uraian tersebut hipotesis yang di ajukan adalah sebagai berikut:

\section{$\mathrm{H}_{1}$ : Terdapat Pengaruh Positif Keputusan Pendanaan, Keputusan Investasi Dan Profiitabilitas Terhadap Nilai Perusahaan.}

\section{Keputusan Pendanaan Terhadap} Nilai Perusahaan

Mokhamat dan Denica (2010) menemukan bahwa keputusan pendanaan berpengaruh positif dan signifikan terhadap nilai perusahaan.

Hal ini dapat diartikan bahwa peningkatan hutang diartikan oleh pihak luar sebagai tanda atau signal positif dari perusahaan dalam kemampuan perusahaan untuk membayar kewajiban dimasa yang akan datang. Berdasarkan uraian tersebut hipotesis yang di ajukan adalah sebagai berikut:

\section{$\mathrm{H}_{2}$ : Terdapat Pengaruh Positif Keputusan Pendanaan, Terhadap Nilai Perusahaan.}

\section{Keputusan Investasi Terhadap} Nilai Perusahaan

Oktaviana (2013), Hesti dan Abriyani (2013) mengemukakan bahwa keputusan investasi berpengaruh positif dan signifikan terhadap nilai perusahaan. Begitu pula dengan hasil peneleitian yang dilakukan oleh Leli dan Barbara (2011) yang mengemukakan bahwa keputusan investasi berpengaruh signifikan terhadap nilai perusahaan.

Hal ini dapat diartikan bahwa keputusan investasi memiliki salah satu aspek utama yaitu onvestasi modal. Pengeluaran investasi yang dilakukan perusahaan akan memberikan signal positif mengenai pertumbuhan perusahaan dimasa yang akan datang. Sehingga dapat meningkatkan harga saham yang digunakan sebagai indikator 
nilai perusahaan. Berdasarkan uraian tersebut hipotesis yang di ajukan adalah sebagai berikut:

$\mathrm{H}_{3}$ : Terdapat Pengaruh Positif Keputusan Investasi Terhadap Nilai Perusahaan

4. Profitabilitas Terhadap Nilai Perusahaan

Ayu dan Ary (2013) menemukan bahwa profitabilitas berpengaruh positif dan signifikan terhadap nilai perusahaan. Pendapat ini didukung oleh hasil penelitian Bhekti (2013), Ummi, dkk (2012) yang menemukan bahwa profitabilitas yang diukur melalui ROE berpengaruh terhadap nilai perusahaan.

Hal ini berarti semakin tinggi nilai profit yang didapat maka akan semakin tinggi nilai perusahaan. Karena dengan profit yang tinggi perusahaan akan mampu membayarkan dividen dan dapat memakmurkan pemegang saham. Berdasarkan uraian diatas, maka hipotesis yang dapat dirumuskan adalah sebagai berikut:

$\mathrm{H}_{4}$ : Terdapat Pengaruh Positif Keputusan Investasi Terhadap Nilai Perusahaan

\section{METODE PENELITAN}

Pendekatan penelitian yang digunakan dalam penelitian ini adalah penelitian kuantitatif yang berasal dari data sekunder berupa laporan tahuan perusahaan yang menekankan pada pengujian hipotesis yang didukung oleh teori dan fakta dengan menggunakan model regresi linier berganda yang terdapat dalam SPSS 21 yang digunakan untuk menguji pengaruh Keputusan
Pendanaan, Keputusan Investasi dan Profitabilitas terhadap Nilai Perusahaan. Variabel dependen dalam penelitian ini adalah nilai perusahaan didefinisikan sebagai nilai pasar akhir tahun karena, perusahaan dapat memberikan kesejahteraan atau kemakmuran pemegang saham secara maksimum apabila harga saham perusahaan meningkat.

Variabel independen merupakan variable yang mempengaruhi atau yang menjadi sebab perubahannya atau timbulnya variable dependen (Sugiyono, 2012). Variabel independen pada penelitian ini adalah sebagai berikut :

\section{Keputusan Pendanaan}

Keputusan pendanaan merupakan keputusan yang menyangkut komposisi pendanaan yang dipilih oleh perusahaan (Hasnawati, 2005 dalam Leli dan Barbara, 2011). Keputusan pendanaan diukur menggunakan Debt to Equity Ratio (DER) yang diambil dari total hutang dibagi total ekuitas.

\section{Keputusan Investasi}

Keputusan investasi adalah kombinasi aktiva yang dimiliki (assets in place) dan pilihan investasi di masa yang akan datang dengan net present value positif (Myers, 1977 dalam Leli dan Barbara, 2011). Keputusan investasi diukur menggunakan Price Earning Ratio (PER). Harga pasar per saham dalam penelitian ini menggunakan closing price

\section{Profitabilitas}

Rasio profitabilitas menghitung kemampuan perusahaan dalam mendapatkan keuntungan. Dalam penelitian ini diukur menggunakan 
Return on Equity (ROE) untuk mengukur profitabilitas perusahaan. Rasio ROE adalah rasio laba bersih terhadap ekuitas saham biasa, yang mengukur tingkat pengembalian atas investasi dari pemegang saham biasa (Agus dan Martono, 2012).

\section{Metode Pengumpulan Data}

Data yang digunakan dalam penelitian ini adalah data sekunder. Data sekunder diperoleh dari situs resmi Bursa Efek Indonesia dengan menggunakan metode dokumentasi. Data sekunder yang dibutuhkan yaitu informasi keuangan dari laporan keuangan tahunan perusahaan yang telah dipublikasikan dari tahun 2011-2014 yang termasuk dalam sampel dan sesuai dengan variabel yang diteliti.

\section{Metode Analisis Data}

Dalam suatu penelitian jenis data dan hipotesis sangat menentukan ketepatan dalam pemulihan alat uji. Untuk menguji hipotesis dalam penelitian ini digunakan tahapan analisis data sebagai berikut:

\section{Uji Asumsi Klasik}

\section{Uji Normalitas}

Menurut Ghozali (2012) uji normalitas dapat dilihat dalam normal probability plot yang membandingkan distribusi kumulatif dari dari distribusi normal. Distribusi normal akan membentuk satu garis lurus diagonal. Data dapat dikatakan normal jika data atau titik-titik tersebar disekitar garis diagonal dan penyebarannya mengikuti garis diagonal.

\section{Uji Multikolinearitas}

Uji multikolonearitas bertujuan untuk menguji apakah dalam model regresi ditemukan adanya korelasi antar variabel bebas (independen). Model regresi yang baik seharusnya terjadi korelasi di antara variabel independen. Jika variabel independen saling berkorelasi, maka variabel-variabel ini tidak orthogonal. Variabel ortogonal adalah variabel independen yang nilai korelasi antar sesama variabel independen sama dengan nol (Sugiyono, 2012)

\section{Uji Autokorelasi}

Uji Autokolerasi dilakukan untuk menguji apakah dalam regresi linear ada kolerasi antara kesalahan penggangu pada periode $t$ dengan kesalahan pengganggu pada periode $\mathrm{t}-1$ dinilai dengan menggunakan uji durbin Watson (Ghozali, 2012). Dengan dasar pengambilan keputusan, sebagai berikut:

Tabel 1.

Pengambilan Keputusan Uji Autokolerasi

\begin{tabular}{|l|l|l|}
\hline $\begin{array}{l}\text { Hipotesis } \\
\text { Nol }\end{array}$ & Keputusan & Jika \\
\hline $\begin{array}{l}\text { Tidak ada } \\
\text { autokorela } \\
\text { si positif }\end{array}$ & Tolak & $0<\mathrm{d}<\mathrm{d} 1$ \\
\hline $\begin{array}{l}\text { Tidak ada } \\
\text { autokorela } \\
\text { si positif }\end{array}$ & No decision & $\mathrm{d} 1 \leq \mathrm{d} \leq \mathrm{du}$ \\
\hline $\begin{array}{l}\text { Tidak ada } \\
\text { autokorela } \\
\text { si negative }\end{array}$ & Tolak & $4-\mathrm{d} 1<\mathrm{d}<4$ \\
\hline $\begin{array}{l}\text { Tidak ada } \\
\text { autokorela } \\
\text { si negative }\end{array}$ & No decition & 4-du $\leq \mathrm{d} \leq 4-$ \\
\hline $\begin{array}{l}\text { Tidak ada } \\
\text { autokorela } \\
\text { si positif }\end{array}$ & Tdk ditolak & $\mathrm{du}<\mathrm{d}<(4-\mathrm{du})$ \\
\hline
\end{tabular}


atau

negative

Sumber : Ghozali, 2012

\section{Uji Heteroskedastisitas}

Uji heteroskedastisitas bertujuan untuk menguji apakah dalam model regresi yang dipakai dalam penelitian terjadi ketidaksamaan variance dari residual satu pengamatan ke pengamatan yang lainnya. Jika variance dari residual atau satu pengamatan ke pengamatan lain tetap maka disebut Homoskedastisitas dan jika berbeda disebut Heteroskedastisitas (Ghozali, 2012).

\section{Statistik Deskriptif}

Statistik deskriptif menjelaskan nilai minimum, maksimum, mean, dan deviasi standar dari variabel-variabel yang digunakan dalam penelitian ini. Dalam penelitian ini analisis statistik deskriptif digunakan untuk mengetahui gambaran mengenai komisaris independen, komite audit dan kualitas audit terhadap penghindaran pajak pada perusahaan sektor industri barang konsumsi yang terdaftar di Bursa Efek Indonesia (BEI) periode 2010-2014.

\section{Regresi Linear Berganda}

Analisis regresi berganda digunakan untuk menguji pengaruh lebih dari satu variabel bebas terhadap satu variabel terikat (Ghozali, 2012). Analisis yang digunakan untuk menguji pengaruh keputusan pendanaan, keputusan investasi dan profitabilitas terhadap nilai perusahaan dengan menggunakan regresi berganda dengan tingkat signifikan 5 persen. Untuk menguji model tersebut maka digunakan analisis regresi berganda dengan rumus sebagai berikut:

$$
\mathbf{Y}=\alpha+\boldsymbol{\beta}_{1} \mathbf{X}_{1}+\boldsymbol{\beta}_{2} \mathbf{X}_{2}+\boldsymbol{\beta}_{3} \mathbf{X}_{3}+\mathbf{e}
$$

Dimana:

$$
\begin{array}{ll}
\mathrm{Y} & =\text { tobin's } \mathrm{q} \\
\alpha & =\text { konstanta } \\
\beta_{1} \beta_{2} \beta_{3}=\text { koefisien regresi berganda } \\
\mathrm{X}_{1} \quad=\text { debt to equity ratio (DER) } \\
\mathrm{X}_{2} \quad=\text { price earning ratio (PER) } \\
\mathrm{X}_{3} \quad=\text { return on equity (ROE) } \\
\mathrm{e} & =\text { error }
\end{array}
$$

\section{Uji Statistik F (F-test)}

Uji statistik $\mathrm{f}$ digunakan untuk mengetahui apakah variabel independen secara bersama-sama atau simultan mempengaruhi variabel dependen (Ghozali, 2012). Pengujian ini dilakukan dengan menggunakan tingkat signifikan $5 \%$. Jika nilai $\mathrm{f}<0,05$ artinya terdapat pengaruh yang signifikan antara variabel independen terhadap variabel dependen. Jika nilai $f>0,05$ artinya tidak terdapat pengaruh antara variabel independen terhadap variabel dependen.

\section{Uji Statistik t (Uji t-test)}

Uji statistik $t$ digunakan untuk mengetahui pengaruh masing-masing variabel independen terhadap variabel dependen (Ghozali, 2012). Pengujian ini dilakukan dengan menggunakan tingkat signifikan 5\%. Jika nilai signifikan $\mathrm{t}<$ 0,05 artinya terdapat pengaruh yang signifikan antara satu variabel independen terhadap variabel dependen. Jika nilai $t>0,05$ artinya tidak terdapat pengaruh antara satu variabel independen terhadap variabel dependen (Ghozali, 2012).

\section{Uji Adjusted R Square (R2)}

Pengujian ini digunakan untuk mengetahui tingkat ketepatan yang 
terbaik dalam analisis regresi dalam hal ini ditujukan oleh besarnya koefisien determinasi. Wibowo (2012) dalam Ta'dir (2014) menyatakan bahwa Adjust $R^{2}$ digunakan untuk menilai koefisien determinasi jika model regresi yang digunakan dalam penelitian memiliki lebih dari dua variabel independen. Koefisien determinasi digunakan untuk mengetahui presentase pengaruh variabel independen terhadap variabel dependen. Menurut Ghozali (2012) menyatakan bahwa nilai adjusted $\mathrm{R}^{2}$ mempunyai interval nol sampai satu $(0$ $R^{2}$ 1). Nilai $R^{2}$ (mendekati 1) maka variabel-variabel independen dapat menjelaskan semua informasi yang dibutuhkan untuk memprediksi variasi variabel dependen.

\section{HASIL DAN PEMBAHASAN Uji Normalitas}

Dalam penelitian ini pengujian normalitas dilakukan dengan Uji One Sample Kolmogorov - Smirnov Test yang dilakukan terhadap data residual model regresi. Hasil uji normalitas data yang diperoleh sebagai berikut:

Tabel 2.

\section{Hasil Uji Normalitas}

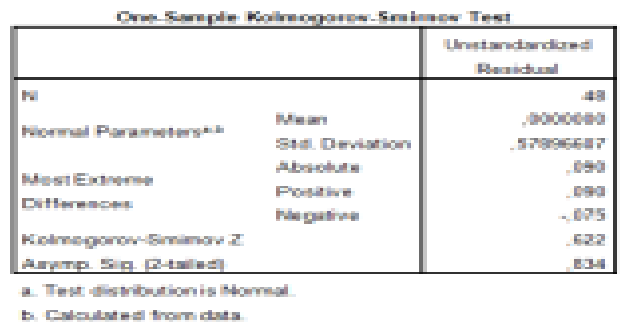

dilihat bahwa nilai KolmogorovSmirnov sebesar 0,622 dan nilai dari Asymp. Sig (2-tailed) sebesar 0,834 dimana nilai Asymp. Sig (2-tailed) lebih besar dari tingkat signifikansi 5 persen sehingga penelitian ini berdistribusi normal.

\section{Uji Multikolinearitas}

Suatu model regresi dinyatakan bebas dari multikolonearitas apabila nilai Tolerance diatas 0,10 dan nilai VIF dibawah 10. Untuk mengetahui apakah terjadi multikolonearitas atau tidak dapat dilihat dari hasil uji multikolonearitas pada tabel berikut ini:

Tabel 3

Hasil Uji Multikolinearitas

Coefficients $^{a}$

\begin{tabular}{|c|c|c|c|}
\hline & \multirow{2}{*}{ Model } & \multicolumn{2}{|c|}{ Collinearity Statistics } \\
\hline & & Tolerance & VIF \\
\hline & (Constant) & & \\
\hline 1 & DER & 971 & 1,030 \\
\hline & PER & ,878 & 1,139 \\
\hline & ROE & ,867 & 1,154 \\
\hline
\end{tabular}

Berdasarkan hasil output SPSS koefisien Tolerance pada variabel lebih besar dari angka 0,10 dan VIF $<10$. Hal ini mengindikasikan bahwa tidak terjadi gejala multikolonearitas.

\section{Uji Autokorelasi}

Untuk menganalisis ada atau tidaknya autokorelasi dalam penelitian ini dipakai uji Durbin Watson. Hasil uji autokorelasi setelah outlier dapat dilihat pada tabel dibawah ini:

Tabel 4

\section{Hasil Uji Autokorelasi}

\begin{tabular}{|l|r|}
\hline Model & Durbin-Watson \\
\hline 1 & 1,827 \\
\hline
\end{tabular}

a. Predictors: (Constant), PER, DER, ROE

b. Dependent Variable: TB 
Hasil output SPSS model summary setelah outlier besarnya nilai $\mathrm{DW}_{\text {hitung }}$ adalah 1,827. Nilai $\mathrm{DW}_{\text {tabel }}$ dengan $\mathrm{n}=41$ dan $\mathrm{k}=3$ didapat angka $\mathrm{d}_{\mathrm{L}}=1,3480$ dan $\mathrm{d}_{\mathrm{u}}=1,6603$. Nilai tersebut berada diantara nilai $d_{u}$ tabel dan nilai 4 $-\mathrm{d}_{\mathrm{u}}\left(\mathrm{d}_{\mathrm{u}}<\mathrm{d}<4-\mathrm{d}_{\mathrm{u}}\right)$, hal ini mengindikasikan tidak terjadi autokorelasi dalam penelitian ini.

\section{Uji Heteroskedastisitas}

Model regresi yang baik adalah yang homokedastisitas atau tidak terjadi heteroskedastisitas (Ghozali, 2012). Hasil pola grafik scatterplot ditunjukkan pada gambar dibawah ini:

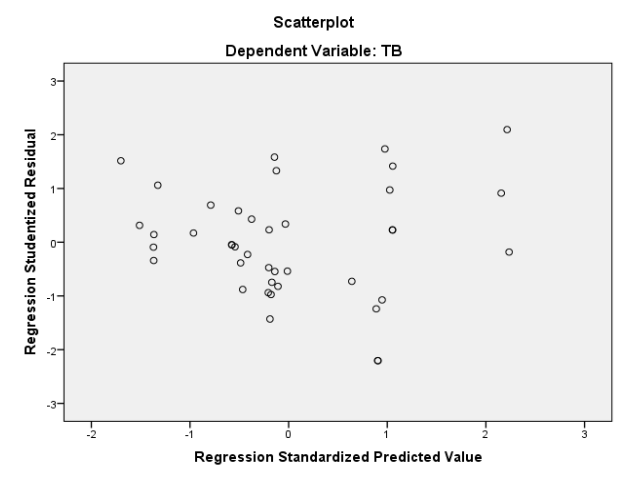

Gambar 1

Scatterplot

Hasil dari grafik scatterplot menunjukkan bahwa tidak terdapat pola yang jelas serta titik-titik menyebar diatas dan dibawah angka 0 pada sumbu Y secara acak sehingga dapat disimpulkan bahwa dalam penelitian ini tidak terjadi heteroskedastisitas.

\section{Statistik Deskriptif}

Hasil dari masing-masing variabel akan ditunjukkan pada tabel berikut:

Tabel 5

Hasil Analisis Statistik Deskriptif

\begin{tabular}{|l|r|r|r|r|r|r|}
\hline & N & Minimum & Maximum & \multicolumn{1}{c|}{ Sum } & Mean & Std. Deviation \\
\hline TB & 48 & .30 & 4.30 & 58.70 & 1.2229 & .83239 \\
DER & 48 & .20 & 7.40 & 53.20 & 1.1083 & 1.21442 \\
PER & 48 & 3.10 & 1250.00 & 2858.00 & 59.5417 & 196.18884 \\
ROE & 48 & .00 & .40 & 6.70 & .1396 & .10051 \\
ValidN & 48 & & & & & \\
(listwise) & 48 & & & & & \\
\hline
\end{tabular}

Berdasarkan tabel diatas dapat diketahui bahwa nilai maksimum untuk keputusan pendanaan sebesar 7,40 diwakilkan oleh perusahaan JECC dan nilai minimumnya adalah 0,20 diwakilkan oleh perusahaan INDS sedangkan nilai mean sebesar 1,1083 dengan nilai standar deviasinya adalah 1,21442. Nilai maksimum untuk keputusan investasi sebesar 1250,00 diwakilkan oleh perusahaan STAR dan nilai minimumnya adalah 3,10 diwakilkan oleh perusahaan JECC sedangkan nilai mean sebesar 59,5417 dengan nilai standar deviasinya adalah 196,18884. Nilai maksimum untuk profitabilitas sebesar 0,40 diwakilkan oleh perusahaan SMSM dan nilai minimumnya adalah 0,00 diwakilkan oleh perusahaan STAR dan UNIT sedangkan nilai mean sebesar 0,1396 dengan nilai standar deviasinya adalah 0,10051 . Nilai perusahaan memiliki nilai maksimum sebesar 4,30 diwakilkan oleh perusahaan SMSM dan nilai minimumnya adalah 0,30 diwakilkan oleh perusahaan UNIT sedangkan nilai mean sebesar 1,229 dengan nilai standar deviasinya adalah 0,83239 .

\section{Regresi Linier Berganda}

Analisis regresi berganda bertujuan untuk menganalisis pengaruh langsung keputusan pendanaan, keputusan investasi, dan profitabilitas yang merupakan variabel independen terhadap nilai perusahaan yang 
merupakan variabel dependen. Hasil pengujian dari analisis regresi berganda dapat dilihat pada tabel dibawah ini:

Tabel 6

Hasil Regresi Linier Berganda

\begin{tabular}{|c|c|c|c|}
\hline \multirow[t]{2}{*}{ Model } & \multicolumn{2}{|c|}{$\begin{array}{l}\text { Unstandardized } \\
\text { Coefficients }\end{array}$} & $\begin{array}{l}\text { Standardized } \\
\text { Coefficients }\end{array}$ \\
\hline & B & $\begin{array}{l}\text { Std. } \\
\text { Error }\end{array}$ & Beta \\
\hline (Constant) & ,468 &, 157 & \\
\hline DER &,- 149 & ,084 &,- 196 \\
\hline PER & ,001 & ,001 & ,129 \\
\hline ROE & 6,002 & ,881 &, 811 \\
\hline
\end{tabular}

Hasil regresi linear berganda dapat dimasukkan dalam persamaan menjadi:

TB = 0,468 - 0,149 DER + 0,001 PER + 6,002 ROE

\section{Uji Statistik F}

Pengujian ini dilakukan dengan menggunakan tingkat signifikan $5 \%$ atau 0,05 . Hasil uji signifikansi simultan (Uji F) tampak pada tabel dibawah ini:

Tabel 7

\section{Hasil Uji F}

\begin{tabular}{|ll|c|c|}
\hline \multicolumn{2}{|l|}{ Model } & F & Sig. \\
\hline \multicolumn{1}{|c|}{$\begin{array}{l}\text { Regression } \\
1\end{array}$} & $\begin{array}{l}\text { Residual } \\
\text { Total }\end{array}$ & & \\
\hline
\end{tabular}

a. Dependent Variable: TB

b. Predictors: (Constant), PER, DER, ROE

Hasil uji ANOVA atau $F$ test

didapat nilai $\mathrm{F}_{\text {hitung }}$ sebesar 16,466 atau lebih besar dari nilai $\mathrm{F}_{\text {tabel }}$ sebesar 2,86 dengan tingkat signifikansi sebesar 0,000 atau lebih kecil dari tingkat signifikansi $5 \%$ atau 0,05 . Hal ini menunjukkan bahwa keputusan pendanaan (DER), keputusan investasi
(PER) dan profitabilitas (ROE) secara bersama-sama (simultan) berpengaruh positif dan signifikan terhadap nilai perusahaan (Tobin's q) sehingga $\mathbf{H}_{\mathbf{1}}$ Diterima.

\section{Uji Statistik t}

Pengujian ini dilakukan dengan menggunakan tingkat signifikan 5\% atau 0,05 dengan derajat kebebasan $\mathrm{df}=\mathrm{n}-\mathrm{k}$ dengan $\mathrm{n}$ adalah jumlah data dan $\mathrm{k}$ adalah jumlah variabel independen. Maka nilai dari df dalam penelitian ini sebesar 37 yaitu (41-4). Hasil uji parsial (Uji t) dapat dijelaskan sebagai berikut:

Tabel 8

Hasil Uji t

\begin{tabular}{|rl|r|r|}
\hline Model & & \multicolumn{1}{c|}{$\mathrm{t}$} & \multicolumn{1}{c|}{ Sig. } \\
& & & \\
& & & \\
\hline \multirow{4}{*}{1} & (Constant) & 3,513 &, 001 \\
& DER &,- 328 &, 745 \\
& PER & $-1,057$ &, 297 \\
& ROE & 6,456 &, 000 \\
\hline
\end{tabular}

a. Dependent Variable: TB

Pengujian pada hipotesis $2\left(\mathrm{H}_{2}\right)$ menunjukkan tingkat signifikansi sebesar 0,745 atau lebih besar dari 0,05 $(0,745>0,05)$ dan nilai $t_{\text {hitung }}$ sebesar 0,328 atau $(-0,328<2,026)$ yang artinya keputusan pendanan tidak memiliki pengaruh yang signifikan terhadap nilai perusahaan sehingga $\mathbf{H}_{2}$ Ditolak.

Pengujian pada hipotesis $3\left(\mathrm{H}_{3}\right)$ menunjukkan tingkat signifikansi sebesar 0,297 atau lebih besar dari 0,05 $(0,297>0,05)$ dan nilai $t_{\text {hitung }}$ sebesar 1,057 atau $(-1,057<2,026)$ yang artinya keputusan investasi tidak memiliki pengaruh yang signifikan terhadap nilai perusahaan sehingga $\mathbf{H}_{3}$ Ditolak.

Pengujian pada hipotesis $4\left(\mathrm{H}_{4}\right)$ menunjukkan tingkat signifikansi 
sebesar 0,000 atau lebih kecil dari 0,05 $(0,000<0,05)$ dan nilai $t_{\text {hitung }}$ sebesar 6,456 atau $(6,456>2,026)$ yang artinya profitabilitas berpengaruh positif dan signifikan terhadap nilai perusahaan sehingga $\mathbf{H}_{4}$ Diterima.

\section{Uji Koefisien Determinasi $\left(\mathbf{R}^{\mathbf{2}}\right)$}

Nilai $R^{2}$ yang kecil berarti kemampuan variabel-variabel independen dalam menjelaskan variabel dependen amat terbatas. Sebaliknya nilai $\mathrm{R}^{2}$ mendekati satu berarti variabelvariabel independen memberikan hampir semua informasi yang dibutuhkan untuk memprediksi variabel dependen (Ghozali, 2012). Hasil uji koefisien determinasi $\left(\mathrm{R}^{2}\right)$ tampak pada tabel dibawah ini:

Tabel 9

\section{Hasil Koefisien Determinasi}

\begin{tabular}{|l|c|r|r|}
\hline Model & $\mathrm{R}$ & $\begin{array}{c}\mathrm{R} \\
\text { Square }\end{array}$ & \multicolumn{1}{c|}{$\begin{array}{c}\text { Adjusted } \mathrm{R} \\
\text { Square }\end{array}$} \\
\hline 1 &, $756^{\mathrm{a}}$ &, 572 &, 537 \\
\hline
\end{tabular}

Hasil uji koefisien determinasi diketahui nilai adjusted $\mathrm{R}^{2}$ sebesar 0,537 atau $53,7 \%$. Hal ini menunjukkan bahwa perubahan nilai perusahaan dipengaruhi oleh keputusan pendanaan (DER), keputusan investasi (PER) dan profitabilitas (ROE) sebesar 53,7\% dan sisanya $46,3 \%$ dipengaruhi oleh faktor lain yang tidak termasuk dalam model regresi.

\section{Intepretasi Hasil dan Pembahasan}

Variabel keputusan pendanaan yang disajikan pada tabel 4.20 menunjukkan nilai $t_{\text {hitung }}$ sebesar $-0,328$ atau $(-0,328<2,026)$ dengan nilai signifikansi sebesar 0,745 lebih besar dari $0,05(0,745>0,05)$. Hal ini menunjukkan bahwa variabel keputusan pendanaan yang diukur menggunakan DER tidak memiliki pengaruh yang signifikan terhadap nilai perusahaan (Hipotesis 2 ditolak).

Artinya tinggi rendahnya DER tidak mempengaruhi nilai perusahaan, karena hutang merupakan salah satu sumber pembiayaan yang memiliki tingkat risiko yang tinggi. Risiko tersebut berhubungan dengan risiko pembayaran bunga yang umumnya tidak dapat ditutupi perusahaan. Sehingga risiko tersebut dapat menurunkan nilai perusahaan.

Variabel keputusan investasi yang disajikan pada tabel 4.20 menunjukkan nilai $t_{\text {hitung }}$ sebesar $-1,057$ atau $(-1,057<2,026)$ dengan nilai signifikansi sebesar 0,297 lebih besar dari 0,05 atau $(0,297>0,05)$. Hal ini menunjukkan bahwa variabel keputusan investasi yang diukur menggunakan PER tidak memiliki pengaruh yang signifikan terhadap nilai perusahaan (Hipotesis 3 ditolak).

Artinya naik turunnya PER tidak berpengaruh terhadap nilai perusahaan. Hal ini disebabkan karena tingkat risiko investasi yang akan ditanggung dimasa yang akan datang sesuai dengan besaran invetsasi yang dilakukan sehingga mempengaruhi kepercayaan investor untuk menginvestasikan sejumlah dana kepada perusahaan tersebut.

Variabel profitabilitas yang disajikan pada tabel 4.20 menunjukkan nilai $t_{\text {hitung }}$ sebesar 6,456 atau $(6,456>$ $2,026)$ dengan nilai signifikansi sebesar 0,000 lebih kecil dari 0,05 atau $(0,000<$ $0,05)$. Hal ini menunjukkan bahwa variabel profitabilitas yang diukur menggunakan ROE berpengaruh positif 
dan signifikan terhadap nilai perusahaan (Hipotesis 4 diterima).

Artinya semakin tinggi nilai profit yang didapat maka akan semakin tinggi nilai perusahaan. Karena profit yang tinggi akan memberikan indikasi prospek perusahaan yang baik sehingga dapat memicu investor untuk ikut meningkatkan permintaan saham. Permintaan saham yang meningkat akan menyebabkan nilai perusahaan yang meningkat.

\section{KESIMPULAN}

\section{DAN REKOMENDASI}

\section{Kesimpulan}

Berdasarkan hasil analisis data tentang pengaruh keputusan pendanaan, keputusan investasi dan profitabilitas secara simultan maupun parsial terhadap nilai perusahaan pada perusahaan manufaktur sektor aneka industri yang terdaftar di Bursa Efek Indonesia (BEI) periode 2011-2014, diperoleh kesimpulan sebagai berikut:

1. Terdapat pengaruh signifikan positif keputusan pendanaan (DER), keputusan investasi (PER) dan profitabilitas (ROE) terhadap nilai perusahaan. Hal ini ditunjukkan dengan nilai $\mathrm{F}_{\text {hitung }}$ sebesar 16,466 atau $(16,466>2,86)$ dan signifikansi sebesar 0,000 atau $(0,000<0,05)$. Artinya naik turunnya suatu nilai perusahaan sangat dipengaruhi oleh keputusan pendanaan, keputusan investasi dan profitabilitas perusahaan tersebut.

2. Tidak terdapat pengaruh signifikan keputusan pendanaan (DER) terhadap nilai perusahaan. Hal ini ditunjukkan dengan nilai $\mathrm{t}_{\text {hitung }}$ sebesar $-0,328$ atau $(-0,328<$ 2,026) dan signifikansi sebesar
0,745 atau $(0,745>0,05)$. Artinya keputusan pendanaan tidak mempengaruhi nilai perusahaan.

3. Tidak terdapat pengaruh signifikan keputusan investasi (PER) terhadap nilai perusahaan. Hal ini ditunjukkan dengan nilai $\mathrm{t}_{\text {hitung }}$ sebesar $-1,057$ atau $(-1,057<$ 2,026) dan signifikansi sebesar 0,297 atau $(0,297>0,05)$. Artinya tinggi rendahnya suatu nilai perusahaan tidak dipengaruhi oleh keputusan investasi.

4. Terdapat pengaruh signifikan positif profitabilitas (ROE) terhadap nilai perusahaan. Hal ini ditunjukkan dengan nilai $t_{\text {hitung }}$ sebesar 6,456 atau $(6,456>2,026)$ dan signifikansi sebesar $0,000<$ 0,05 . Artinya semakin tinggi nilai profit yang didapat suatu perusahaan maka nilai perusahaan akan semakin tinggi.

\section{Rekomendasi}

Berdasarkan kesimpulan dan keterbatasan pada penelitian ini, maka dapat disampaikan beberapa saran sebagai berikut:

\section{Bagi Penulis}

Penelitian ini diharapkan dapat menambah ilmu pengetahuan dan wawasan bagi penulis. Serta bemanfaat bagi kehidupan penulis kedepannya.

\section{Bagi Perusahaan}

Sebagai salah satu pertimbangan bagi manajer keuangan dalam mengambil keputusan pendanaan dan keputusan investasi guna tercapainya tujuan perusahaan dalam memperoleh laba (profit) yang sebesar-besarnya dalam 
rangka memaksimalkan nilai perusahaan.

3. Bagi Investor

Penelitian ini diharapkan dapat memberikan informasi mengenai faktor-faktor yang mempengaruhi nilai perusahaan yaitu profitablitas.

4. Bagi Akademik

Penelitian ini diharapkan dapat dijadikan referensi yang dapat memberikan informasi teoritis kepada pihak-pihak yang akan melakukan penelitian lebih lanjut mengenai penelitian ini serta menambah sumber pustaka yang telah ada.

\section{Bagi Peneliti Selanjutnya}

a. Penelitian selanjutnya diharapkan dapat mengembangkan penelitian dengan faktor lain yang mempengaruhi nilai perusahaan diluar peneliitan ini.

b. Penelitian selanjutnya dapat memperbaiki keterbatasan yang ada dalam penelitian ini dan menambah sektor lain dari perusahaan manufaktur yang terdaftar di Bursa Efek Indonesia (BEI).

c. Penelitian selanjutnya dapat memperbaiki keterbatasan yang ada dalam penelitian ini dan memperbanyak jumlah sampel serta tahun pengamatan untuk mendapatkan hasil yang menyeluruh.

\section{DAFTAR PUSTAKA}

Ayu Sri Mahatma Dewi dan Ary Wirajaya. 2013. "Pengaruh Struktur Modal, Profitabilitas dan Ukuran Perusahaan pada Nilai Perusahaan". Dalam E-Jurnal Akuntansi
Univesritas Udayana, Volume 4, No 2 Hal 358-372. Universitas Udayana.

Bhekti Fitri Prasetyorini. 2013. "Pengaruh Ukuran Perusahaan, Leverage, Price Earning Ratio dan Profitabilitas Terhadap Nilai Perusahaan". Dalam Jurnal Ilmu Manajemen, Volume 1 No $1 \mathrm{Hal}$ 183-196. Universitas Negeri Surabaya.

Dermawan Sjahrial. 2014. Manajemen Keuangan Lanjutan Edisi 1. Jakarta: Mitra Wacana Media.

Fahmi Irham. 2013. Pengantar Manajemen Keuangan Edisi 2. Bandung: Alfabeta.

Ghozali Imam. 2012. Aplikasi Analisis Miltivariate dengan Program IBM SPSS 20 Edisi 6. Semarang: Badan Penerbit Universitas Diponegoro.

Harjito Agus dan Martono. 2012. Manajemen Keuangan Edisi 2. Yogyakarta: Ekonisia.

Johan Ruth Prapaska dan Siti Mutmainah. 2012. "Analisis Pengaruh Tingkat Profitabilitas, Keputusan Investasi, Keputusan Pnedaaan, dan Kebijakan Dividen Terhadap Nilai Perusahaan pada Perusahaan Manufaktur di BEI 2009-2010”. Dalam Diponegeoro Journal Of Accounting, Volume 1. No 1 Hal 1-12. Universitas Diponegoro.

Juan Ng Eng dan Wahyuni Ersa Tri. 2012. Panduan Praktis Standar Akuntansi Keuangan Berbasis IFRS Edisi 2. Jakarta: Salemba Empat.

Kasmir. 2010. Pengantar Manajemen Keuangan Edisi 1. Jakarta: Kencana Prenada Media Group.

Leli Amnah Rakhimsyah dan Barbara Gunawan. 2011. "Pengaruh 
Keputusan Investasi, keputusan Pendanaan, Kebijakan Dividen dan Tingkat Suku Bunga Terhadap Nilai Perusahaan". Dalam Jurnal Investasi, Volume 7. No 1 Hal 3145. Universitas Muhammadiyah Yogyakarta.

Mokhamat Ansori dan Denica H.N. 2010. "Pengaruh Keputusan Investasi, Keputusan Pendanaan dan Kebijakan Dividen Terhadap Nilai Perusahaan pada Perusahaan yang Tergabung dalam Jakarta Islamic Index Studi pada Bursa Efek Indonesia (BEI)". Dalam Jurnal Analisis Manajemen, Volume 4, No 2 Hal 153-175. Universitas Muria Kudus.

Mulyadi. 2001. Akuntansi Manajemen Edisi 3. Jakarta: Salemba Empat.

Oktaviana Tiara Sari. 2013. "Pengaruh Keputusan Investasi, Keputusan Pendanaan dan Kebijakan Dividen Terhadap Nilai Perusahaan”. Dalam Management Analysis Journal, Volume 2, No. 2 Hal 1-7. Universitas Negeri Semarang.

Prihadi Toto. 2009. Deteksi Cepat Kondisi Keuangan 7 Analisis Rasio Keuangan Edisi 1. Jakarta: PPM Manajemen

Rahmawati. 2012. Teori Akuntansi Keuangan Edisi 1. Yogyakarta: Graha Ilmu.

Sugiyono. 2012. Metodologi Penelitian Bisnis Edisi 16. Bandung: Alfabeta.

Ta'dir Eko Prasetia, Parengkuan Tommy dan Ivone S. Saerang. 2014. "Struktur Modal, Ukuran Perusahaan dan Risiko Perusahaan Terhadap Nilai Perusahaan Otomotif Terdaftar di BEI". Dalam Jurnal EMBA, Volume 2, No 2 Hal
879-889. Universitas Sam Ratulangi Manado.

Ummi Mardiyati, Gatot Nazir Ahmad dan Ria Putri. 2012. "pengaruh kebijakan dividen, kebijakan hutang dan profitabilitas terhadap nilai perusahaan manufaktur yang terdaftar di Bursa Efek Indonesia (BEI) periode 2005-2010". Dalam Jurnal Riset Manajemen Sains Indonesia (JRMSI), Volume 3, No. 1 Hal 1-17. Universitas Negeri Jakarta.

Yulia Efni. 2012. "Keputusan Investasi, Keputusan Pendanaan dan Kebijakan Dividen: Pengaruhnya Terhadap Nilai Perusahaan (Studi pada Sektor Properti dan Real estate di Bursa Efek Indonesia). Dalam Jurnal Aplikasi Manajemen, Volume 10, No 1 Hal 128-141. Universitas Riau. 